\title{
NERACA AIR LAHAN UNTUK PENGEMBANGAN TANAMAN KELAPA SAWIT (Elaeis guinensis Jacq), DI KECAMATAN SANGKUB, KABUPATEN BOLAANG MONGONDOW UTARA
}

\author{
Silvana E. Kaeng \\ Johannes E.X. Rogi \\ Jantje Pongoh
}

\begin{abstract}
This study aims to find out the water balance in Sangkub Sub-district, North Bolaang Mongondow Regency for oil palm cultivation with water balance simulation model developed by Handoko (1994) and Rogi (2002). The study was conducted from May - December 2016. This research uses simulation model method; the data used in this research is secondary data. The data analysis used run model of water balance of land and formula calculation of land water balance. The study found that the amount of water surplus from the run of the water balance model and calculations based on the formula in one year cannot meet the water requirements of oil palm crops, so that oil palm plantations cannot be cultivated in Sangkub Sub-district. This is due to the existence of rice cultivated crops prior to oil palm cultivation, where both plants require relatively large amount of water.
\end{abstract}

Keywords : land water balance, Palm Oil, Sangkub Sub-district, North Bolaang Mongondow Regency

\begin{abstract}
ABSTRAK
Penelitian ini bertujuan untuk mengetahui neraca air di Kecamatan Sangkub, Kabupaten Bolaang Mongondow Utara untuk budidaya kelapa sawit dengan model simulasi neraca air yang dikembangkan oleh Handoko (1994) dan Rogi (2002). Penelitian ini dilakukan dari bulan Mei Desember 2016 di Kecamatan Sangkub, Kabupaten Bolaang Mongondow Utara. Penelitian ini menggunakan metode model simulasi, data yang digunakan dalam penelitian ini adalah data sekunder. Analisis data menggunakan run model neraca air lahan dan rumus perhitungan neraca air lahan. Studi ini menemukan bahwa jumlah surplus air dari run model neraca air lahan dan perhitungan berdasarkan rumus dalam satu tahun tidak dapat memenuhi kebutuhan air dari tanaman kelapa sawit, sehingga tanaman kelapa sawit tidak dapat dibudidayakan di Kecamatan Sangkub. Hal ini disebabkan adanya tanaman padi yang telah dibudidayakan terlebih dahulu sebelum tanaman kelapa sawit dibudidayakan, dimana kedua tanaman tersebut membutuhkan air yang relatif banyak.
\end{abstract}

Kata kunci : Neraca Air Lahan, Kelapa Sawit Kecamatan Sangkub, Kabupaten Bolaang Mongondow Utara 


\section{PENDAHULUAN}

\section{Latar Belakang}

Kelapa sawit (Elaeis guinensis jacq) adalah tanaman perkebunan yang penting, karena kelapa sawit dapat menghasilkan minyak goreng, minyak untuk industri, maupun bahan bakar nabati (biodiesel). Kegunaan tersebut menjadikan kelapa sawit merupakan salah satu tanaman perkebunan yang memiliki nilai ekonomi yang cukup tinggi. Menurut Anonimous (2013a) perkebunan kelapa sawit di Indonesia merupakan yang terluas di dunia. Hal ini menempatkan Indonesia sebagai negara pengekspor utama minyak kelapa sawit mentah (CPO : crude palm oil) dan berbagai olahannya. Tahun 2011 luas areal kelapa sawit Indonesia mencapai 8,91 juta $\mathrm{Ha}$, dengan rincian luas areal Perkebunan Besar Swasta (PBS) sebesar 4,65 juta Ha (52,22\%), luas areal Perkebunan Rakyat (PR) sebesar 3,62 juta Ha (40,64\%), dan luas areal Perkebunan Besar Negara (PBN) sebesar 0,64 juta Ha $(7,15 \%)$ (Anonimous, 2013b). Tawaran yang cukup mengiurkan dari hasil kelapa sawit, sehingga membuat perusahan-perusahan swasta dan pemerintah berusaha untuk meningkatkan produksi kelapa sawit dengan melakukan kegiatan perluasan areal pertanaman, rehabilitasi kebun yang sudah ada dan intensifikasi. Wilayah Sulawesi Utara, termasuk Bolaang Mongondow utara, merupakan salah satu wilayah yang dilirik untuk dilakukan perluasan areal perkebunan kelapa sawit. Air merupakan faktor yang utama bagi kegiatan di bidang pertanian, karena semua proses metabolisme tanaman terjadi karena adanya air. Perkembangan dan produktivitas tanaman akan baik jika kondisi air tanahnya dalam keadaan yang optimum. Untuk mengetahui kondisi atau keadaan air di suatu areal maka indikator yang digunakan adalah neraca air. Sulistio (2001) mengatakan bahwa dengan diketahui status neraca airnya, maka suatu areal yang mendapat input hanya dari curah hujan saja misalnya, maka akan dapat dikelola dengan baik, pola tanam dapat diatur dan dapat menekan resiko kegagalan panen. Tersedianya air dapat juga untuk menentukan cocok tidaknya suatu areal pertanian untuk setiap macam tanaman tanpa adanya pengairan yang teratur (irigrasi). Oleh sebab itu dalam mengembangkan suatu areal pertanian, kondisi air lahan harus menjadi perhatian utama. Secara umum setiap tanaman termasuk kelapa sawit memerlukan air untuk keberhasilan budidayanya. Kondisi neraca air lahan menjadi perhatian utama untuk pengembangan kelapa sawit.

\section{Tujuan Penelitian}

Penelitian ini bertujuan untuk menghitung neraca air lahan di Kecamatan Sangkub, Kabupaten Bolaang Mongondow Utara untuk budidaya tanaman kelapa sawit dengan menggunakan model simulasi neraca air yang dikembangkan oleh Handoko (1994) dan Rogi (2002).

\section{Manfaat Penelitian}

Manfaat penelitian ini : Untuk dapat dijadikan rekomendasi bagi budidaya tanaman kelapa sawit di Kec. Sangkub, Kab. Bolaang Mongondow Utara.

\section{METODOLOGI PENELITIAN}

\section{Waktu dan Lokasi Penelitian}

Penelitian ini dilaksanakan mulai bulan Mei - Desember 2016 bertempat di Kecamatan Sangkub kabupaten Bolaang Mongondow Utara.

\section{Metode Pengumpulan Data}

Metode Pengumpulan Data yang digunakan dalam penelitian ini terdiri dari : data iklim bulanan (Curah hujan dan Evapotranspirasi Potensial/ETP) tahun 2015, Letak koordinat Kecamatan Sangkub, kebutuhan air tanaman kelapa sawit. Sedangkan alat yang digunakan dalam penelitian ini adalah : perangkat lunak (software) neraca air lahan, model pembangkit unsur cuaca Shierary Weather Versi 2.0, seperangkat computer.

\section{Metode Pengambilan Sampel}

Penelitian ini menggunakan metode model simulasi, data yang digunakan dalam penelitian ini adalah data sekunder. Data sekunder yang di ambil berupa data iklim, yaitu data curah hujan dan Avapotranspirasi Potensial (ETP) tahun 2015, yang merupakan data bangkitan hasil run model. Data yang diperoleh dimasukkan dalam aplikasi neraca 
air, kemudian dijelaskan. Data iklim diperoleh dari model pembangkit unsure cuaca Shierary Weather versi 2.0. Kemudian data keluaran berupa curah hujan $(\mathrm{CH})$ dan Evapotranspirasi Potensial (ETP) tersebut dimasukkan dalam software neraca air lahan dengan desain proses sebagai berikut:

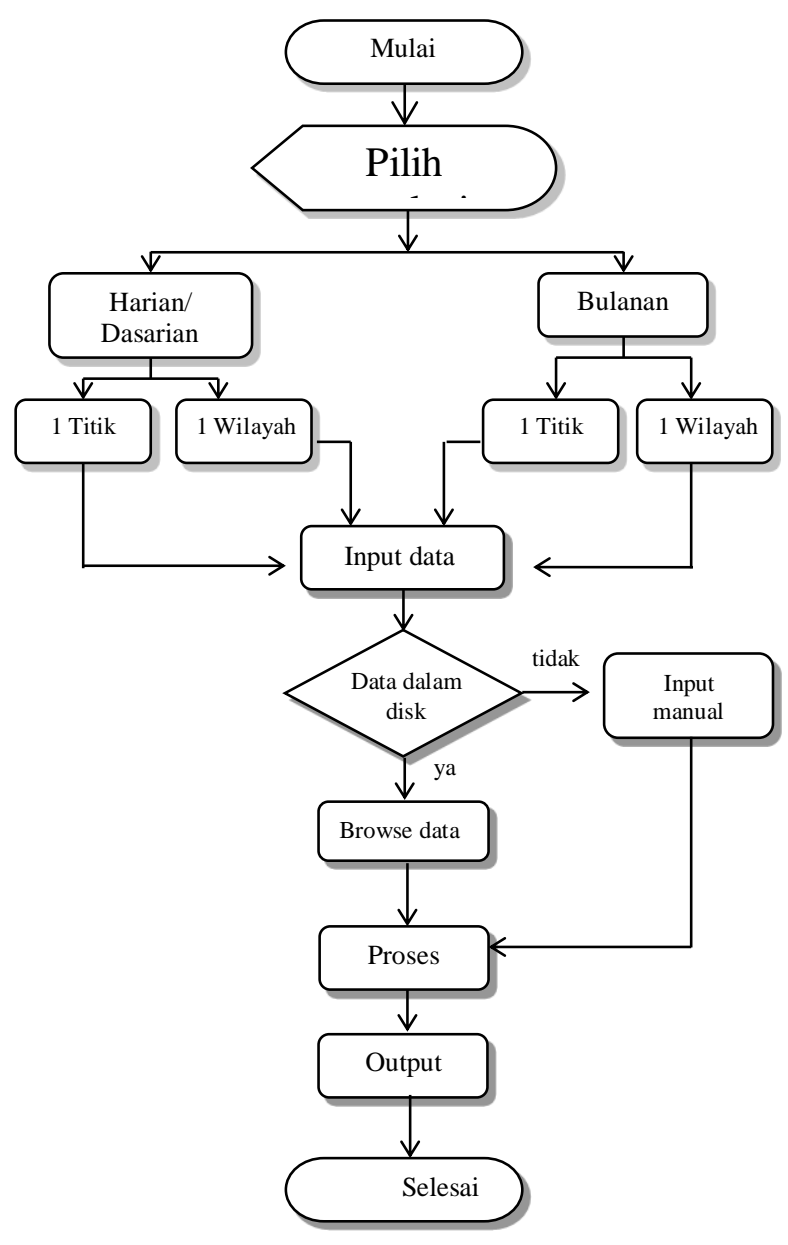

Gambar 1. Diagram alir Proses Neraca Air Lahan Kelapa Sawit

Desain proses bertujuan untuk mendesain proses yang berawal dari bagaimana memasukkan data input diteruskan dengan bagaimana sistem mengolah data input sampai menghasilkan keluaran (output), yaitu berupa : data cuaca, data evapotranspirasi, surplus air, defisit air, kadar air tanah/KAT. Sebagai pembanding, data juga dihitung dengan menggunakan rumus. Adapun rumusan perhitungan neraca air di kecamatan sangkub antara lain:

a) $\mathrm{CH}$ (curah hujan) diperoleh dari model pembangkit unsure cuaca Shierary Weather versi 2.0 b) ETP (evapotranspirasi potensial) diperoleh dari model pembangkit unsure cuaca Shierary - Weather versi 2.0

c) APWL (accumulation off potential water losses $)=$ akumulasi nilai $\mathrm{CH}-\mathrm{ETP}$ yang bernilai negative (1)

d) $\operatorname{KAT}($ Kadar Air Tanah $)=$ KL x k ${ }^{2}$ (2)

Dengan catatan bahwa:

$\mathrm{KL}=$ kapasitas lapang $(\mathrm{mm})$

$\mathrm{k}=$ nilai ketetapan, dimana $\mathrm{k}=\mathrm{po}+\mathrm{pi} / \mathrm{KL}$ (dimana, po $=1,000412351$; pi $=-1,073807306$ )

e) $\mathrm{dKAT}=\mathrm{KAT}_{\mathrm{i}}-\mathrm{KAT}_{\mathrm{i}_{-1}}$

f) ETA (evapotranspirasi aktual), adalah jika $\mathrm{CH}>\mathrm{ETP}$, maka ETA = ETP dan jika $\mathrm{CH}$ $<\mathrm{ETP}$, maka ETA $=\mathrm{CH}+$ dKATnegatif (4)

g) $\quad$ Defisit $=$ ETP - ETA (5)

h) Surplus $=\mathrm{CH}-\mathrm{ETP}-$ Dkat (6)

\section{HASIL DAN PEMBAHASAN}

Kecamatan sangkub secara geografis terletak di katulistiwa dengan posisi antara $0^{\circ} 50^{\prime} \mathrm{LU}$ dan $123,3^{\circ}-123,4^{\circ}$ BT. Gambar peta Kecamatan Sangkub, Kabupaten Bolaang Mongondow Utara disajikan pada gambar 2 di bawah ini.

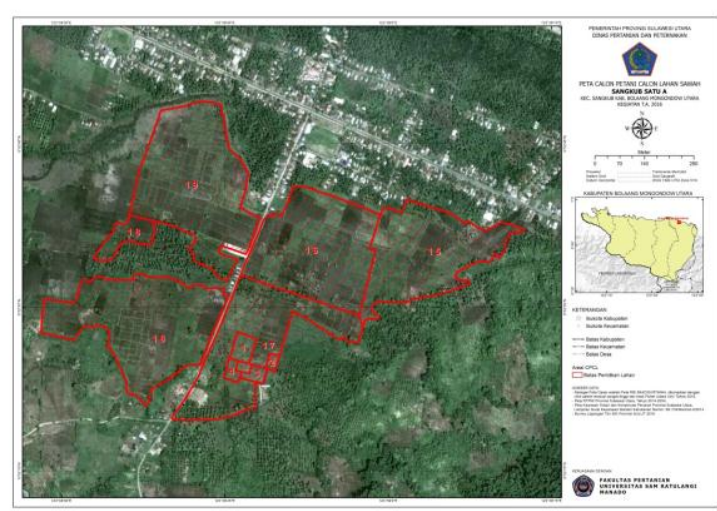

Gambar 2. Peta Kecamatan Sangkub Kabupaten Bolaang Mongondow Utara

Hasil run model pembangkit unsur cuaca Shierary - Weather versi 2.0 diperoleh data iklim seperti curah hujan, hari hujan, dan evapotranspirasi. Data iklim bulanan hasil run 
model di Kecamatan Sangkub dapat kita baca pada Tabel 1.

\begin{tabular}{|c|c|c|c|c|c|}
\hline Lintang & Bujur & bulan & $\begin{array}{c}\mathbf{C h} \\
(\mathbf{m m})\end{array}$ & $\begin{array}{c}\text { Hh } \\
\text { (hari) }\end{array}$ & $\begin{array}{c}\text { ETP } \\
(\mathbf{m m})\end{array}$ \\
\hline 0,5 & 123,3 & 1 & 338,95 & 14 & 115,04 \\
\hline 0,5 & 123,3 & 2 & 237,63 & 12 & 108,08 \\
\hline 0,5 & 123,3 & 3 & 251,57 & 9 & 119,95 \\
\hline 0,5 & 123,3 & 4 & 307,86 & 13 & 113,80 \\
\hline 0,5 & 123,3 & 5 & 280,85 & 12 & 116,18 \\
\hline 0,5 & 123,3 & 6 & 421,73 & 12 & 103,41 \\
\hline 0,5 & 123,3 & 7 & 202,30 & 12 & 112,67 \\
\hline 0,5 & 123,3 & 8 & 213,61 & 12 & 118,17 \\
\hline 0,5 & 123,3 & 9 & 145,91 & 9 & 119,14 \\
\hline 0,5 & 123,3 & 10 & 198,50 & 11 & 122,29 \\
\hline 0,5 & 123,3 & 11 & 142,70 & 10 & 115,48 \\
\hline 0,5 & 123,3 & 12 & 217,29 & 11 & 116,84 \\
\hline Jumlah & & & 2958,90 & 137 & 1381,05 \\
\hline
\end{tabular}

Perhitungan neraca air berupa surplus dan defisit air dimaksudkan untuk mengetahui apakah Kecamatan Sangkub dapat dikembangkan kelapa sawit. Perhitungan dilakukan dengan run model maupun menggunakan persamaan. Perhitungan kebutuhan air tanaman kelapa sawit diperoleh berdasarkan tabel kesesuaian lahan kelapa sawit menurut Allorerung (2010), yaitu dapat dilihat pada Tabel 2

Tabel 2. Kesesuaian iklim kelapa sawit

\begin{tabular}{|c|c|c|c|c|}
\hline Iklim & Baik & Sedang & $\begin{array}{l}\text { Kurang } \\
\text { Baik }\end{array}$ & $\begin{array}{l}\text { Tidak } \\
\text { Baik }\end{array}$ \\
\hline $\begin{array}{l}\text { Curah hujan } \\
\text { (mm) }\end{array}$ & $\begin{array}{l}2000- \\
2500\end{array}$ & $\begin{array}{l}1800- \\
2000\end{array}$ & $\begin{array}{l}1500- \\
1800\end{array}$ & $<1500$ \\
\hline $\begin{array}{l}\text { Deficit air } \\
\mathrm{mm} / \mathrm{thn}\end{array}$ & $0-150$ & $\begin{array}{l}150- \\
200\end{array}$ & $250-400$ & $>400$ \\
\hline $\begin{array}{l}\text { Hari } \\
\text { terpanjang } \\
\text { tidak hujan }\end{array}$ & $\begin{array}{l}<10 \\
\text { hari }\end{array}$ & $\begin{array}{ll}< & 10 \\
\text { hari } & \end{array}$ & $<10$ hari & $<10$ hari \\
\hline $\begin{array}{l}\text { Temperature } \\
\left({ }^{\circ} \mathrm{C}\right)\end{array}$ & $\begin{array}{l}22 \\
23\end{array}$ & $22-23$ & $22-23$ & $22-23$ \\
\hline $\begin{array}{l}\text { Penyinaran } \\
\text { (jam) }\end{array}$ & 6 & 6 & $<6$ & $<6$ \\
\hline Kelembaban & 80 & 80 & $<80$ & $<80$ \\
\hline
\end{tabular}

Tabel 2, kesesuaian lahan yang menyatakan kebutuhan air tanaman kelapa sawit, apabila dibandingkan dengan jumlah curah hujan di Kecamatan Sangkub pada Tabel 1 mencapai 2958,90 menunjukkan kategori baik. Artinya berdasarkan jumlah curah hujan yang diperoleh dari data pembangkit cuaca pada tahun 2015, menyatakan cukup tersedia bagi tanaman kelapa sawit. Tetapi seperti diketahui Kabupaten Boloaang Mongondow Utara menyebut daerahnya sebagai kabupaten padi.
Ini diperoleh dari data terakhir tahun 2009 Kabupaten Bolaang Mongondow Utara mampu menghasilkan komoditas tanaman pangan masing-masing sebanyak 25.943 ton padi (sawah + ladang) merupakan $9 \%$ dari jumlah produksi kabupaten Bolaang Mongondow sebelum dimekarkan. Jumlah tersebut diperoleh dari luas tanam berjumlah 5.211 Hektar $( \pm 9 \%)$ Luas lahan sawah dan ladang Kabupaten Bolaang Mongondow (Anonimous, 2012). Sebagian besar wilayah sangkub adalah perkebunan dan persawahan. Berdasarkan data dari Anonimous (2016) luas lahan sawah di Kecamatan Sangkub berjumlah total 1.804,6 Hektar, yang terdiri atas 850 Hektar sawah irigasi dan 954,60 sawah bukan irigasi. Tanaman padi sawah juga merupakan tanaman yang membutuhkan air yang cukup banyak, yaitu pada lahan kering (tanpa irigasi) tanaman padi membutuhkan curah hujan yang optimum $>1600 \mathrm{~mm} /$ tahun (Anonimous, 2009).

Atas pertimbangan tersebut maka dilakukan perhitungan neraca air di Kecamatan Sangkub, untuk mengetahui bulan-bulan surplus air dan jumlah surplus air dalam satu tahun.

Data curah hujan dan evapotranspirasi potensial (ETP) dari Tabel 1, kemudian di input ke dalam aplikasi neraca air lahan. Setelah data di input, maka diperoleh data keluaran (output) kadar air tanah (KAT), defisit air, dan surplus air. Data keluaran aplikasi neraca air lahan dapat dilihat pada Tabel 3.

\begin{tabular}{clcl}
\multicolumn{2}{c}{ Tabel 3. Data Kadar Air Tanah } & KAT), Defisit, & \multicolumn{1}{c}{ Surplus bulanan } \\
\hline Bulan & KAT & Defisit & \multicolumn{1}{c}{ Surplus } \\
\hline 1 & 300 & 0 & 38,37 \\
2 & 281,79 & 0 & 0 \\
3 & 300 & 0 & 67,44 \\
4 & 300 & 0 & 105,30 \\
5 & 291,85 & 0 & 0 \\
6 & 300 & 0 & 111,99 \\
7 & 300 & 0 & 67,27 \\
8 & 294,1 & 0 & 0 \\
9 & 259,55 & 0 & 0 \\
10 & 192,97 & 9,32 & 0 \\
11 & 149,76 & 19,35 & 0 \\
12 & 242,57 & 0 & 0 \\
\hline
\end{tabular}


Neraca air bulanan di Kecamatan Sangkub selain di hitung dengan menggunakan aplikasi model, juga dihitung dengan menggunakan rumus (1), (2), (3), (4), (5), (6). Tabel 4 adalah perhitungan neraca air bulanan di Kecamatan Sangkub dengan menggunakan rumus dan dibandingkan dengan hasil run model.

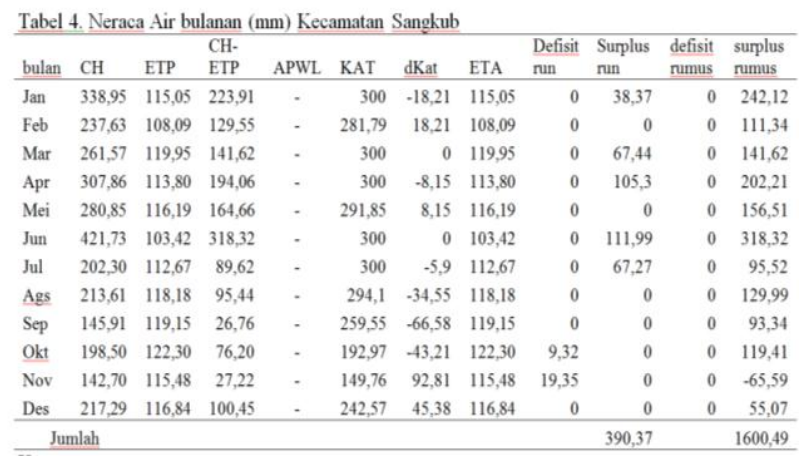

Keterangan :

$\begin{array}{ll}\begin{array}{l}\text { CH } \\ \text { ETP } \\ (\mathrm{mm})\end{array} & \text { : Curah hujan } \\ \text { APWL } & \text { : Akumotranspirasi Potensial } \\ & \begin{array}{l}\text { kehilangan air (Acucumulation } \\ \text { off potential water losses) }\end{array} \\ \text { KAT } & \text { : Kadar air tanah }(\mathrm{mm}) \\ \text { dKAT } & \text { : selisih (delta) KAT }(\mathrm{mm}) \\ \text { Surplus } & \text { : Kelebihan air }(\mathrm{mm}) \\ \text { Deficit } & \text { : Kekurangan air }(\mathrm{mm})\end{array}$

Analisis data neraca air pada Tabel 4 diperoleh 5 bulan surplus pada hasil keluaran aplikasi run model, yaitu pada bulan Januari, Maret, April, Juni, dan Juli dengan jumlah surplus dalam setahun adalah 390,37 mm/tahun, dan 11 bulan surplus pada hasil perhitungan rumus (6), yaitu pada bulan Januari - Oktober dan bulan desember, dengan jumlah surplus dalam setahun adalah 1600,49 mm/tahun. Jumlah surplus dalam setahun pada Tabel 4 tersebut apabila dibandingkan dengan kebutuhan air tanaman kelapa sawit sudah jauh berada di bawah. Artinya surplus air di Kecamatan Sangkub tidak bisa memenuhi kebutuhan air dari tanaman kelapa sawit.

Menurut penelitian dari Sari dkk (2017), tanaman kelapa sawit membutuhkan air yang cukup banyak pada lima tahun pertama pertumbuhannya. Apabila tanaman mengalami kekurangan air, akan menghambat pertumbuhan awal, baik pertumbuhan vegetatif maupun produksi awal tanaman. Air sangat berperan dalam proses fisiologis tanaman, seperti transport hara dari akar ke tanaman dan proses fotosintesis. Apabila kebutuhan air tanaman tidak terpenuhi, maka proses-proses penting tersebut akan terhambat, dan nantinya akan menghambat proses pertumbuhan tanaman, dan mengurangi produksi tanaman pula. Terjadi kekurangan air akan mengakibatkan proses fotosintesis tanaman terganggu karena terjadi pengurangan dalam pembentukan dan perluasan daun. Ketersediaan air juga mempengaruhi pemupukan terhadap tanaman, karena air berperan dalam melarutkan unsur hara yang diberikan terhadap tanaman (Manalu, 2008).

\section{KESIMPULAN}

Berdasarkan hasil analisis neraca air lahan dan keseluruhan uraian dalam pembahasan, maka dapat diambil beberapa kesimpulan sebagai berikut :

1. Dari data keluaran model neraca air lahan, Kecamatan Sangkub mengalami 5 bulan surplus air, yaitu pada bulan Januari, Maret, April, Juni dan Juli dengan jumlah surplus setahun adalah $390,37 \mathrm{~mm} /$ tahun

2. Perhitungan rumus surplus air (rumus 6), Kecamatan Sangkub mengalami 11 bulan surplus air, yaitu pada bulan Januari Oktober dan Desember dengan jumlah surplus setahun adalah $1600,49 \mathrm{~mm} /$ tahun

3. Jumlah surplus air hasil run model neraca air lahan dan perhitungan rumus (6) dalam satu tanun tidak bisa memenuhi kebutuhan air dari tanaman kelapa sawit, sehingga tanaman kelapa sawit tidak bisa di budidayakan di Kecamatan Sangkub apabila di taman bersamaan dengan tanaman padi sawah yang sudah di kembangkan di Kecamatan Sangkub selama bertahun-tahun.

Berdasarkan kesimpulan di atas, maka dapat diberikan saran sebagai berikut :

Budidaya atau perluasan tanaman kelapa sawit di Kecamatan sangkub dapat dilakukan bersamaan dengan penanaman padi sawah apabila pemerintah setempat bekerja sama dengan masyarakat untuk membangunan sistem 
irigasi yang baik untuk memenuhi kebutuhan air tanaman kelapa sawit dan juga kebutuhan air tanaman padi sawah.

\section{DAFTAR PUSTAKA}

Allorerung, D, Syakir. M, Poeloengan. Z, Syafrudin, Rumini. R, 2010. Budidaya Kelapa Sawit. Pusat

Anonimous, 2009. Budidaya Tanaman Padi. Badan Ketahanan Pangan dan Penyuluh Pertanian Aceh. Bekerja Sama dengan Balai Pengkajian Teknologi Petanian NAD. Aceh

Annonimous, 2012. Buku Putih Sanitasi. Percepatan Pembangunan Sanitasi Pemukiman, Kabupaten Bolaang Mongondow Utara.

Annonimous, 2013a. Market Brief Kelapa Sawit Dan Olahannya. Kementrian Perdagangan Republik Indonesia (Ministry of Trade), ITPC Hamburg, Jerman.

Anonimous, 2013b. Informasi Ringkas Komoditas Perkebunan. Pusat Data Dan Sistem Informasi Pertanian. Departemen Pertanian, Jakarta.

Annonimous, 2016. Kabupaten Bolaang Mongondow Utara Dalam Angka. Badan Pusat Statistik Kabupaten Bolaang Mongondow
Handoko, 1994. Dasar Penyusunan dan Aplikasi Model Simulasi Komputer untuk Pertanian, Jurusan Agromet IPB

Manalu Agus Frans, 2008. Pengaruh Hujan Terhadap Produktivitas Dan Pengelolaan Air Di Kebun Kelapa Sawit (Elaeis Guinensis) Mustika estate, PT. Sajang Heulang, Minamas Plantation, Tanah Bumbu, Kalimantan Selatan. Program Studi Agronomi. Fakultas Pertanian. Institut Pertanian Bogor. Bogor.

Rogi, X.E.Johannes. 2002. Penyusunan Model Simulasi Dinamika Nitrogen Pertanaman Kelapa Sawit (Elaeis guineensis Jacq.) Di unit Usaha Bekri Provinsi Lampung. Disertasi. Program Pasca Sarjana Institut Pertanian Bogor.

Sari R. J, Ardian, Syafrinal, 2017. Pengaruh Hujan Terhadap Produksi Tanaman Kelapa Sawit di PT. Perkebunan Nusantara V Kebun Tandun. Program Studi Agorteknologi, Fakultas Pertanian, Universitas Riau. Pekanbaru

Sulistio Bambang, 2001. Desain Konstruksi Neraca Air (Studi Kasus Jawa Timur). Institit Pertanian Bogor 